\title{
33 手術台の耐オゾン性一材料試験結果と対応策一
}

古山信明 (千葉大手術部)，䧚橋宽二 (石川島播磨重工業), 河埜吉明（瑞穗医科工業）

第69同本学会において医療機器・器材の觓オゾン性 について総論的に報告したが，今回は感染症手術の終 了倦，手術台を公外に移動せずに手術室内をオン゙ン雳 蒸できれば污染を应散させずにすみ，より高いレベル の感染対策が可能であると考充，手術台を構成してい る部品・材料のオン゙ンの影㗽につき個々に検討した。

[月的]乎術台の耐オゾン性を確認し, 手術台の才 ゾン殺菌に叔ける対応策を得るのが本研究の目的であ 万.

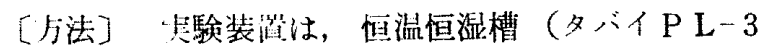
A）にホゾン発生装罚，オン゙ン排出装罚，オゾンモ二 タを設置して構成し, 温度 $30{ }^{\circ} \mathrm{C}$, 湿度 $50 \%$, オン゙ン 浀度 $100 \mathrm{ppm}$ の条件下で，材料試験を行った。 100 , 500,1000 および 1400 時間㭟露後の目視による評栣 (帅波・色調の変化の有無) を基本としたが, さらに 対象により適切な哔価方法を選択した，オゾン酎性の 低いことが既知の材料については，オゾン濃度を 10 ppm とし，基雾時間も短維した。
[結果]手術台本体の骨格をなす鉝属類は，一部の 金属で錆, くもり，热色などオン゙ン $(100 \mathrm{ppm})$ の影 翡を若干らけるが，塗料の材料試験では変化が認めら れなかったことを考えると実際にはめっき・塗装して 使用するため特別の対策は必要ないと考兄られる。 ード，マットなどに使用されるゴム, ウレタン類では, 一部のゴムはオゾンに対して極めて弱く，該当するご ลには材啠の変更，定期的な交換またはビニールなど でカバーする必要がある、ウレタンはウレタンマット としてクッション等に用いられるが，10 ppm です軟 化や黄変がみられオゾンに対して弱いが，カバーがし てあれば聿用上は間题ない、マイクロスイッチ,コネ クターなどの電気部品は $100 \mathrm{ppm}$ で接点抵抗のわず かな增州がみられ，ォゾンにより接点が酸化するが， 涌電比る回復する。

[考察]若干の対応で, 手術台の耐オゾン珄: は离 く,オゾンは価値ある殺菌法になりうる。

\section{4 金属製手術用器具の洗浄後の表面状態の顕徽鏡稓察による表面鋿びの特徵 腐食原因, 防鉝対策について}

本田隆治, 岡 登志子, 上野仁子, 小林寛伊（東京大病院材料部）

洗浄を評価するインジケーターといらものが存在し ないため, 再生使用器具の洗浄が確実に抏こなわれて いるかどらか判断することは非常に困難である。唯一 の基準として考えられることは金属製器具上の錆び・ 着色状態である，このような状態になるには必ず原因 があり，それを解決することにより，よりよい洗浄が 確立される。

しかし金属製器其の中には10年以上使用しているも
のああれば，最近使い始めたるのがあることや，使用 現場によって予洗の方法が異なるなど条件を統一する ことも困難である.

そこで錆び・着色が見られた器具の払出先, 洗浄方 法, 器械の種類, 錆び・着色の部位及び度合いを調查 し，代表的なるのを顕微鏡観察により表面錆びの特 徵，凮食原因を調べ防錆対策を報告する。 